\title{
Effects of methionine plus cysteine inclusion on performance and body composition of liquid-fed crossbred calves fed a commercial milk replacer and no starter feed
}

\author{
J. C. C. Chagas, ${ }^{*}$ M. A. Ferreira, ${ }^{*}$ A. P. Faciola,† F. S. Machado, $\ddagger$ M. M. Campos, $\ddagger$ M. R. Entjes,§ \\ J. L. Donzele,\# and M. I. Marcondes\# ${ }^{1}$ \\ *Department of Animal Science, Universidade Federal Rural de Pernambuco, Pernambuco, 52171-900, Brazil \\ †Department of Animal Sciences, University of Florida, Gainesville 32611 \\ ‡Empresa Brasileira de Pesquisa Agropecuária (EMBRAPA), Juiz de Fora, Minas Gerais, 36038-330, Brazil \\ §Department of Applied Animal Sciences, Van Hall Larenstein University of Applied Sciences, 9001-6880 Velp, the Netherlands \\ \#Department of Animal Science, Universidade Federal de Viçosa, Minas Gerais, 36570-900, Brazil
}

\begin{abstract}
This experiment aimed to evaluate the effects of supplying 4 different inclusion levels of Met + Cys to crossbred liquid-fed calves on animal performance and body composition. Thirty-six Holstein-Gyr male calves were separated into 2 age groups: 16 calves, slaughtered at an age of $30 \mathrm{~d}$, representing the physiological phase from 8 to $30 \mathrm{~d}$, and 20 calves, slaughtered at an age of $60 \mathrm{~d}$, representing the physiological phase from 30 to 60 d. At $8 \mathrm{~d}$ of age, the animals were randomly distributed among the experimental treatments: 4 Met + Cys inclusion levels (Met + Cys: 8.0, 8.7, 9.4, and $10.2 \mathrm{~g} / \mathrm{d}$ ), provided by an AA supplement added to $1.0 \mathrm{~kg}$ (as fed) of commercial milk replacer containing soy protein concentrate and wheat protein isolate reconstituted at $13.8 \%$ (dry matter basis). The diet was supplied without allowing leftovers and no starter feed was provided. The experimental diets were supplied without allowing orts, so that the dry matter, crude protein, and ether extract intakes were the same for all animals, independent of Met + Cys level. Total weight gain, average daily gain, gain composition, and body composition were evaluated for both age groups separately. Digestibility of organic matter, crude protein, and ether extract was lower for 8 to $30 \mathrm{~d}$ than for 30 to $60 \mathrm{~d}$. The effect of Met + Cys levels on the digestibility of nutrients was not observed; there also was no significant interaction between physiological phase and Met + Cys levels. For the 8 to $30 \mathrm{~d}$ group, no responses in performance were observed according to the different Met + Cys levels, which indicates that $8.0 \mathrm{~g} / \mathrm{d}$ of Met + Cys met the requirements for this physiological phase. The 30 to
\end{abstract}

Received July 31, 2017.

Accepted February 19, 2018.

${ }^{1}$ Corresponding author: marcosinaciomarcondes@gmail.com
$60 \mathrm{~d}$ group responded positively to higher Met + Cys inclusion in the diet. In conclusion, an optimal Met + Cys dietary level to ensure best performance and protein gain ranges from 8.41 to $9.81 \mathrm{~g} / \mathrm{d}$.

Key words: sulfur amino acid, lysine, protein gain, calf performance

\section{INTRODUCTION}

Milk is considered the best protein source for young calves due to its high digestibility and balanced AA profile (Huang et al., 2015; Castro et al., 2016). However, only few studies have suggested modifications of the AA profile of liquid diets for dairy calves to promote greater performance (Hill et al., 2008; Wang et al., 2012; Hill et al., 2016). The AFRC (1993), NRC (2001), and CSIRO (2007), which are the main systems used for prediction of nutrient requirements of dairy animals, do not have AA requirements for calves. However, some studies have suggested optimal inclusion levels of essential AA in calf diets (Hill et al., 2008; Wang et al., 2012) and highlighted Met as the main growth-limiting AA for neonates (Erickson et al., 1989; Abe et al., 1997; Wu et al., 2014).

Methionine plays an important metabolic role; about $52 \%$ of the consumed Met is metabolized by intestinal lumen cells and can be converted to $\mathrm{Cys}$ (Wu et al. 1998). Cysteine is a conditionally essential AA for neonates (D'Mello, 2003), which is involved in metabolic pathways that promote animal health and performance (Jankowski, et al., 2014). Thus, Met supply in calves' diets could meet Cys requirements as well.

Thus, we hypothesized that it is possible to find an optimal inclusion level of Met + Cys for crossbreed liquid-fed calves that allows maximum performance from DL-Met supplementation. We also hypothesized that animals up to 4 wk old respond differently to nonmilk protein exclusive milk replacers and an AA supple- 
ment, as exclusive diet, than animals aged between 4 and $8 \mathrm{wk}$. The overall goal of our study was, therefore, to evaluate the effects of supplying 4 different Met + Cys levels in the diets of liquid-fed crossbreed calves of 2 age groups in terms of animal performance and body composition.

\section{MATERIALS AND METHODS}

\section{Ethics Statement}

The experiment was approved by the Institutional Animal Care and Use Committee of the Animal Science Department at the Federal University of Viçosa, registered under protocol number 27/2013.

The experiment was conducted at the Embrapa Dairy Cattle Experimental Farm, located in Coronel Pacheco, Minas Gerais, Brazil. The samples were processed at the Animal Nutrition Laboratory of the Animal Science Department, which belongs to the Federal University of Viçosa, Minas Gerais, Brazil.

\section{Animals and Feeding Management}

Forty-three male calves, whose genetic composition ranged from $1 / 2$ to $15 / 16$ Holstein-Gyr, with a birth weight (BRW) of $36.43 \pm 5.09 \mathrm{~kg}$, were used in the experiment. Immediately after birth, calves were separated from their dams, weighed, and the umbilical cord was immersed in iodine solution $(10 \%)$. Calves were allocated in individual stalls of bedded sand, with free access to water. Colostrum (10\% BRW, $>50 \mathrm{~g} / \mathrm{L}$ of $\operatorname{IgG}$ ) was fed within the first $6 \mathrm{~h}$ after birth; the animals continued to receive colostrum until they were 3 $\mathrm{d}$ old at $10 \%$ BRW; between d 4 and 7 , the calves were fed with $8 \mathrm{~L} / \mathrm{d}$ of raw milk served in aluminum buckets in 2 equal meals (0800 and $1600 \mathrm{~h}$ ).

The serum total protein test (Deelen et al., 2014) was performed between 24 and $48 \mathrm{~h}$ of life using a Brix refractometer (Serum protein REF-301, Biocotek, Beilun, Ningbo, China) to ensure the inclusion of calves in the experiment with minimum levels of immunity transferred from the colostrum $(7 \mathrm{~g}$ of total protein per $\mathrm{dL}$ of blood serum; data not shown).

At $8 \mathrm{~d}$ and with an average BW of $42.06 \pm 4.7 \mathrm{~kg}$, calves with a genetic composition ranging from $1 / 2$ to 15/16 Holstein-Gyr were divided into 2 age groups: group 1: 8 to $30 \mathrm{~d}$ calves, composed of 16 calves slaughtered at an age of $30 \mathrm{~d}$, representing a physiological phase from 8 to $30 \mathrm{~d}$; group 2: 30 to $60 \mathrm{~d}$ calves, composed of 20 calves slaughtered at $60 \mathrm{~d}$ of age, representing a physiological phase from 30 to $60 \mathrm{~d}$. The 36 calves were distributed in a completely randomized block design (8 to $30 \mathrm{~d}, \mathrm{n}=16$ and 4 replications; 30 to $60 \mathrm{~d}, \mathrm{n}=20$ and 5 replications) among the experimental treatments that consisted of 4 Met + Cys inclusion levels (Met + Cys: 8.0, 8.7, 9.4, and $10.2 \mathrm{~g} / \mathrm{d}$; Table 1). The animals were randomly assigned across Met + Cys levels, thus initial BW did not vary among Met + Cys for both age groups and genotypes $(P>0.05$, data not shown).

The 7 remaining animals were slaughtered at $\mathrm{d} 8$ and used as the reference group, with a genetic composition ranging from $1 / 2$ to $15 / 16$ Holstein-Gyr; they were slaughtered at an average BW of $40.14 \pm 4.4 \mathrm{~kg}$. Body composition data of these animals were used to estimate initial body composition of the animals that remained in the experiment.

The calves were fed $1.0 \mathrm{~kg} / \mathrm{d}$ of a milk replacer containing soy protein concentrate and wheat protein isolate (MR; Lacthor, DSM Company, Heerlen, the Netherlands), as fed (Table 1), reconstituted to 13.8\% solids with warm water, prepared individually in aluminum buckets. The diet was supplied without allowing leftovers and no starter feed was provided. Values of Met + Cys were determined through a supply of AA supplement (Ajinomoto Co. Inc., Tokyo, Japan) with increasing levels of DL-Met and decreasing levels of crystalline glutamic acid, providing protein equivalence for experimental diets, where the addition of L-Lys was static (Table 1). Ten grams (DM basis) per meal of amino acidic supplement was diluted in $400 \mathrm{~mL}$ of warm water and offered in plastic bottles to avoid sedimentation of the material in the buckets and to guarantee the complete consumption of the MR; the supplement was given immediately before the MR supply, at 0800 and $1600 \mathrm{~h}$

The AA were included in the diets based on the milk protein amino acidic profile suggested by Rutherfurd and Moughan (1998) and adapted to the AA profile in the commercial MR used in this study (Table 1). The Lys used was adjusted to a suboptimal level (CondeAguilera et al., 2010), assuming that the optimal level of Lys supplied by the milk protein (Rutherfurd and Moughan, 1998) was $19.75 \mathrm{~g} / \mathrm{d}$. Lysine was provided at a suboptimal level to increase the sensitivity of the responses to the rising levels of Met (Conde-Aguilera et al., 2010). The MR and AA supplement was the only source of nutrients fed to the calves to ensure the expected ingestion of $\mathrm{AA}$ and that all responses were due to the formulated diet.

\section{Digestibility Trial}

The animals were weighed at birth and at 8,30 , and $60 \mathrm{~d}$ for performance monitoring. Feed intake was not evaluated because the amount of MR offered from $\mathrm{d} 8$ 
Table 1. Chemical composition ( $\mathrm{g} / 100 \mathrm{~g}$ of DM unless otherwise noted) of commercial milk replacer and intake of feed and AA experimental diets with increasing levels of Met + Cys for liquid-feeding phase calves

\begin{tabular}{|c|c|c|c|c|c|}
\hline \multirow[b]{2}{*}{ Item } & \multirow{2}{*}{$\begin{array}{l}\text { Milk replacer }{ }^{1} \\
\text { composition }\end{array}$} & \multicolumn{4}{|c|}{$\operatorname{Diet}($ Met + Cys $), g / d$} \\
\hline & & 8.0 & 8.7 & 9.4 & 10.2 \\
\hline $\mathrm{DM}, \mathrm{g} / 100 \mathrm{~g}$, as fed & 96.5 & & & & \\
\hline $\mathrm{CP}$ & 21.5 & & & & \\
\hline Ether extract & 15.1 & & & & \\
\hline Crude fiber & 0.74 & & & & \\
\hline \multirow{2}{*}{\multicolumn{6}{|c|}{$\mathrm{AA}^{2}$}} \\
\hline & & & & & \\
\hline Lys & 1.76 & & & & \\
\hline Trp & 0.30 & & & & \\
\hline Thr & 0.88 & & & & \\
\hline Met & 0.30 & & & & \\
\hline Cys & 0.30 & & & & \\
\hline Met + Cys & 0.60 & & & & \\
\hline Val & 0.84 & & & & \\
\hline Ile & 0.86 & & & & \\
\hline Leu & 1.55 & & & & \\
\hline Tyr & 0.47 & & & & \\
\hline Phe + Tyr & 1.20 & & & & \\
\hline Arg & 0.60 & & & & \\
\hline His & 0.39 & & & & \\
\hline Glu & 4.45 & & & & \\
\hline \multicolumn{6}{|l|}{ Feed intake ${ }^{3}$} \\
\hline $\mathrm{CP}, \mathrm{g} / \mathrm{d}$ & & 221 & 221 & 221 & 221 \\
\hline Ether extract, $\mathrm{g} / \mathrm{d}$ & & 146 & 146 & 146 & 146 \\
\hline Crude fiber, $\mathrm{g} / \mathrm{d}$ & & 6.8 & 6.8 & 6.8 & 6.8 \\
\hline Gross energy, kcal/d & & 4,603 & 4,603 & 4,603 & 4,603 \\
\hline \multicolumn{6}{|l|}{ AA intake, ${ }^{4} \mathrm{~g} / \mathrm{d}$} \\
\hline Lys & & 18.2 & 18.2 & 18.2 & 18.2 \\
\hline Trp & & 3.1 & 3.1 & 3.1 & 3.1 \\
\hline Thr & & 9.1 & 9.1 & 9.1 & 9.1 \\
\hline Met & & 5.0 & 5.7 & 6.4 & 7.1 \\
\hline Cys & & 3.0 & 3.0 & 3.0 & 3.0 \\
\hline Met + Cys & & 8.0 & 8.7 & 9.4 & 10.2 \\
\hline Val & & 8.6 & 8.6 & 8.6 & 8.6 \\
\hline Ile & & 8.8 & 8.8 & 8.8 & 8.8 \\
\hline Leu & & 15.8 & 15.8 & 15.8 & 15.8 \\
\hline Tyr & & 4.8 & 4.8 & 4. 8 & 4.8 \\
\hline Phe + Tyr & & 12.4 & 12.4 & 12.4 & 12.4 \\
\hline $\operatorname{Arg}$ & & 6.2 & 6.2 & 6.2 & 6.2 \\
\hline His & & 3.9 & 3.9 & 3.9 & 3.9 \\
\hline Glu & & 56.2 & 55.4 & 54.7 & 53.9 \\
\hline
\end{tabular}

${ }^{1}$ Guaranteed inclusion of lactose ( $42 \%$ as fed; DSM - Lacthor); ingredients: soy protein concentrate, hydrolyzed wheat protein isolate, prebiotic, vitamins $\mathrm{A}, \mathrm{D}_{3}, \mathrm{C}$, and $\mathrm{E}$, cactus oil, and coconut oil.

${ }^{2}$ Essential amino acids of milk replacer.

${ }^{3}$ Feed intake: $0.984 \mathrm{~kg}$ of milk replacer + AA supplement/animal per d.

${ }^{4}$ Amino acid concentration of experimental diets (AA from milk replacer added to AA concentration of each supplement, data corrected for protein equivalent and DM).

onward was the same for all animals, irrespective of age group or Met + Cys. Therefore, considering that the offered diet did not allow orts, there was a total intake of the amount offered during the experiment.

For the digestibility assay, the animals were kept in metabolic cages, wearing collecting funnels adapted to the penile region not to contaminate the feces with urine, and submitted to total feces collection for $72 \mathrm{~h}$ (Silva et al., 2015), starting 5 d before slaughter. The collected feces were weighed, homogenized, sampled, and frozen for subsequent laboratory analysis.

\section{Slaughter}

At the end of the respective trial period for each calf group, calves were slaughtered at an age of 30 or $60 \mathrm{~d}$. The animals were transported in a livestock trailer to the Federal University of Viçosa, Minas Gerais, Brazil, and slaughtered after $16 \mathrm{~h}$ of fasting. The same procedure was performed with the reference group.

Calves were stunned by brain concussion and exsanguinated by jugular venipuncture. After the bleeding procedure, the blood was weighed and sampled. Sub- 
sequently, components of the gastrointestinal tract (rumen, reticulum, omasum, abomasum, and small and large intestines) were washed and weighed to quantify the empty body weight (EBW). Next, rumen, reticulum, omasum, abomasum, small and large intestines, internal fat, mesentery, liver, heart, kidneys, lung, tongue, spleen, diaphragm, esophagus, trachea, reproductive tract, and tail were ground in an industrial grinder to obtain a composite and homogeneous sample of organs and visceral tissue. Hides were weighed, ground, and sampled. Likewise, paws and heads were weighed and ground in an industrial bone grinder and sampled.

The carcass of each animal was divided into 2 halves, which were weighed and then conditioned in a cold room at $4^{\circ} \mathrm{C}$ for approximately $24 \mathrm{~h}$. After this period, carcasses were weighed and each right half-carcass was completely ground in an industrial grinder, forming a carcass sample.

\section{Chemical Analysis and Calculations}

Samples of feces were partially dehydrated in a forced-ventilation oven $\left(55^{\circ} \mathrm{C}\right)$ for $72 \mathrm{~h}$ and subsequently ground to $1 \mathrm{~mm}$. Samples of MR and body components, in turn, were partially dehydrated by lyophilization and ground to $1 \mathrm{~mm}$ in a knife mill (Detmann et al., 2012).

Samples of feeds, feces, and body components were evaluated for their DM, OM, mineral matter (MM), and $\mathrm{CP}$ contents, crude fiber $(\mathbf{C F})$ according to AOAC International (2005), methods 934.01, 942.05, 942.05, 990.13, and 962.09, respectively; ether extract (EE) was determined according to AOCS (2004). Total carbohydrates (TC) were calculated as

$$
\mathrm{TC}=1,000-(\mathrm{CP}+\mathrm{EE}+\mathrm{CA}),
$$

where $\mathrm{CA}=$ crude ash; all values are in grams per kilogram.

The MR AA composition was analyzed using a HPLC, based on reversed-phase chromatography, using the C18 column and an acetonitrile-based gradient (ion-exchange chromatography). The AA extraction was made by protein hydrolysis according to AOAC International (2000) method 982.30. Briefly, 3 hydrolysis were used: acid hydrolysis ( $\mathrm{HCl} 6 M$ ) to quantify resistant AA, NaOH hydrolysis $(\mathrm{NaOH} 4.2 M)$ to tryptophan quantification, and it was adopted the performic acid oxidation (performic acid) and further acid hydrolysis to quantify sulfur AA. The hydrolysis methods were processed in an oxygen-free environment at $110^{\circ} \mathrm{C}$ for $22 \mathrm{~h}$ to liberate $\mathrm{AA}$ from proteins; the derivatizations were made post-column. Tryptophan was detected by fluorescence method. The resistant and sulfur AA were derivatized with 6-aminoquinolil- succimidil-carbamato, separated in reversed phase, and detected by fluorescence method. All AA were detected at 10 to $12 \mathrm{~mol}$ (pmol) limit.

The final body composition of animals was calculated as

$$
\% \mathrm{BC}_{\mathrm{y}}=\mathrm{C}_{\mathrm{y}} /\left(\mathrm{EBW}_{\mathrm{f}}\right) \times 100
$$

where $\mathrm{BC}_{\mathrm{y}}=$ body composition of protein, fat, or ash (\% on DM basis); $\mathrm{C}_{\mathrm{y}}=$ protein, fat, or ash constituent in the final $\mathrm{EBW}(\mathrm{kg})$; and $\mathrm{EBW}_{\mathrm{f}}=$ final $\mathrm{EBW}(\mathrm{kg})$.

The average relationship between EBW and live weight of the reference group was used to estimate the initial EBW of 8 to $30 \mathrm{~d}$, and the average relationship between EBW and live weight of 8 to $30 \mathrm{~d}$ was used to estimate the initial EBW of 30 to $60 \mathrm{~d}$ for each Met + Cys.

\section{Statistical Analysis}

Considering that 16 animals were slaughtered when they were $30 \mathrm{~d}$ old and 20 animals were slaughtered at an age of $60 \mathrm{~d}$, performance data, body composition and protein, EE, and ash gains were evaluated separately for each physiological phase group. The data were evaluated according to a completely randomized block design, where Met + Cys levels were included as quantitative fixed effects in the model, as described below:

$$
\mathrm{Y}_{\mathrm{ijk}}=\boldsymbol{\beta}_{0}+\boldsymbol{\beta}_{1} \times \mathrm{X}_{\mathrm{i}}+\boldsymbol{\beta}_{2} \times \mathrm{X}_{\mathrm{i}}^{2}+\mathrm{G}_{\mathrm{j}}+\boldsymbol{\varepsilon}_{\mathrm{ijk}},
$$

where $Y_{\mathrm{ijk}}$ is the response variable; $\mathrm{X}_{\mathrm{i}}$ is the fixed effect of Met + Cys levels; $G_{j}$ is the random effect of genetic group; $\boldsymbol{\varepsilon}_{\mathrm{ijk}}$ is the general random error; and $\boldsymbol{\beta}_{0}, \boldsymbol{\beta}_{1}$, and $\boldsymbol{\beta}_{2}$ are the parameters of the model.

Breed composition was used as blocking factor, and 2 genetic groups (blocks) were established: crossbred when the genetic composition ranged from $1 / 2$ to $3 / 4$ Holstein-Gyr, and purebred Holstein when it ranged from $7 / 8$ to $15 / 16$ Holstein-Gyr.

Therefore, the Met + Cys values were evaluated regarding their linear and quadratic effects for all variables, and the denominator degrees of freedom were estimated using the Kenward-Roger approximation. When a linear plateau pattern was observed for variables in function of different Met + Cys levels, a linear broken-line analysis was tested, and breakpoints were determined for the following 30 to $60 \mathrm{~d}$ variables: ADG, $\mathrm{CP}$ gain in empty body (EB), and $\mathrm{CP}$ gain in organs and viscera. The broken-line analysis was proceeded using PROC NLIN (SAS 9.4, SAS Institute Inc., Cary, $\mathrm{NC})$ according to the models: 


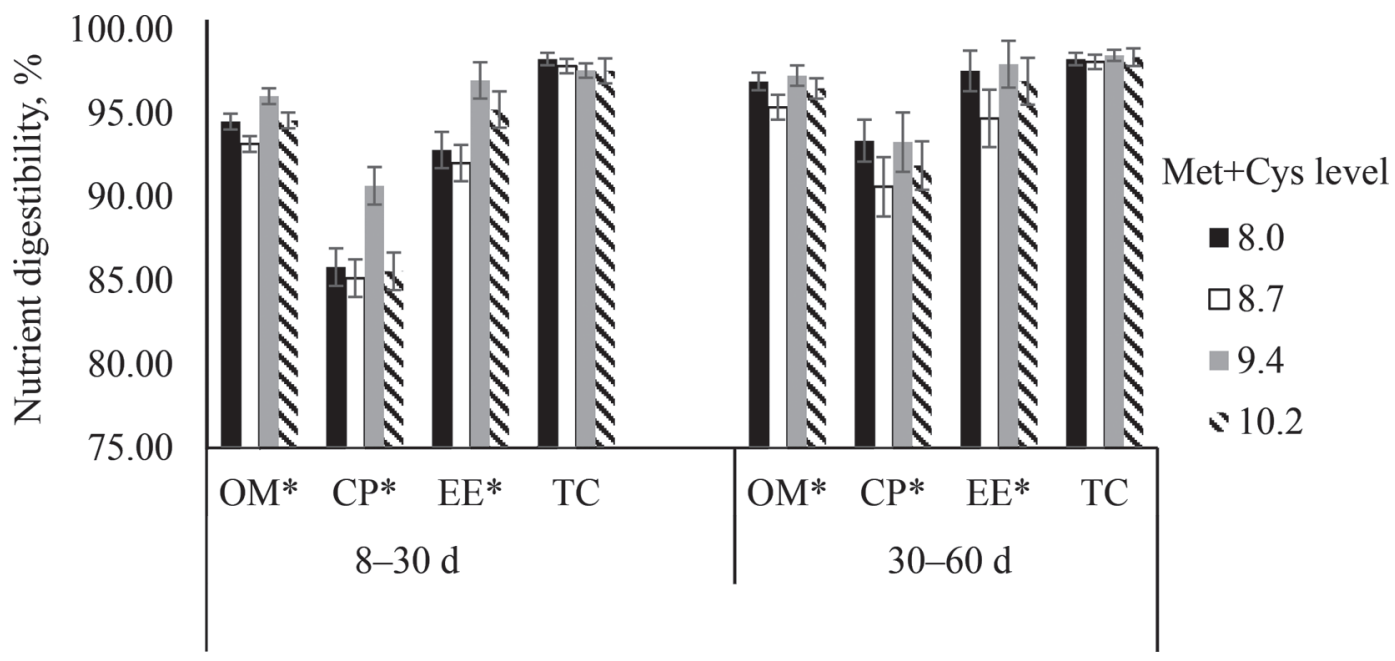

Figure 1. Nutrient digestibility of liquid-fed crossbreed calves in different physiologic phases: newborn calves 8 to $30 \mathrm{~d}$, and pre-weaned calves 30 to $60 \mathrm{~d}$, fed increasing Met + Cys levels $(\mathrm{g} / \mathrm{d}) .{ }^{*} P$-value $<0.001$. EE $=$ ether extract; $\mathrm{TC}=$ total carbohydrates. Error bars represent square mean error of LSM.

$$
\begin{gathered}
\mathrm{Y}_{\mathrm{ijk}}=\boldsymbol{\beta}_{0}+\boldsymbol{\beta}_{1} \times \mathrm{X}_{\mathrm{i}}+\mathrm{G}_{\mathrm{j}}+\mathrm{e}_{\mathrm{ijk}}, \\
\text { when } \mathrm{X}_{\mathrm{i}}<\mathrm{X}_{\text {breakpoint }}, \\
\mathrm{Y}_{\mathrm{ijk}}=\boldsymbol{\beta}_{0}+\boldsymbol{\beta}_{1} \times \mathrm{X}_{\text {breakpoint }}+\mathrm{G}_{\mathrm{j}}+\mathrm{e}_{\mathrm{ijk}}, \\
\text { when } \mathrm{X}_{\mathrm{i}}>\mathrm{X}_{\text {breakpoint }},
\end{gathered}
$$

where $\mathrm{Y}_{\mathrm{ijk}}$ is the response variable, $\mathrm{X}_{\mathrm{i}}$ is the fixed effect of Met + Cys, $\mathrm{X}_{\text {breakpoint }}$ is the Met + Cys value to which there is no more response in $Y_{\mathrm{ijk}}, G_{\mathrm{j}}$ is the random effect of genetic group, and $\mathrm{e}_{\mathrm{ijk}}$ is the general random error.

Two digestibility trials were conducted [one between 25 and $29 \mathrm{~d}(\mathrm{n}=36)$ and one between 55 and $59 \mathrm{~d}$ $(\mathrm{n}=20)]$. The first trial represented the 8 to $30 \mathrm{~d}$ group and the second trial represented the 30 to $60 \mathrm{~d}$ group. Digestibility data were analyzed according to a completely randomized block design in an incomplete repeated measurements scheme.

Variables means were presented accompanied \pm standard error and significance of treatment effects was declared at $P<0.05$ and trend when $0.10<P<0.05$.

\section{RESULTS}

\section{Intake and Nutrient Digestibility}

Dry matter intake, OM intake, CP intake, EE intake, total carbohydrate intake, and mineral matter intake were $984,881,221,146,555$, and $83 \mathrm{~g} / \mathrm{d}$, respectively. Nutrient digestibility varied according to the physiological phase (Figure 1). Average nutrient digestibility for 8 to $30 \mathrm{~d}$ (25-29 d in the experiment) and 30 to 60 d (55-59 d in the experiment), respectively, was 94.56 \pm 0.61 and $96.50 \pm 0.47 \%$ for $\mathrm{OM}(P<0.001), 86.79 \pm$ 0.1 .55 and $92.28 \pm 1.12 \%$ for $\mathrm{CP}(P<0.001), 94.25 \pm$ 1.08 and $96.77 \pm 1.43 \%$ for $\mathrm{EE}(P<0.001)$, and 97.78 and $98.22 \%$ for total carbohydrates $(P>0.05)$. There was no Met + Cys effect on the apparent nutrient digestibility (Figure 1; $P>0.05$ ) as well as no interaction between age and experimental treatments $(P>0.05)$, as shown in Figure 1.

\section{$B W$ and $A D G$}

The final BW did not vary among Met + Cys levels for 8 to $30 \mathrm{~d}$ calves $52.5 \pm 4.74 \mathrm{~kg}$ and 30 to $60 \mathrm{~d}$ calves $68.77 \pm 4.08(P>0.05)$.

Average daily gain of 8 to $30 \mathrm{~d}$ did not differ according to Met + Cys levels $(P=0.656)$, with an ADG of $0.48 \pm 0.01 \mathrm{~kg} / \mathrm{d}$ (Figure 2). The maximum ADG for 30 to $60 \mathrm{~d}$ was obtained at $9.45 \mathrm{~g} / \mathrm{d}$ of Met + Cys according to the broken-line analysis $[\mathrm{Y}=-0.1035+$ $0.0738 \times$ Met + Cys; $P=0.0003 ; \mathrm{R}^{2}=0.600 ;$ mean square error $(\mathrm{MSE})=0.01$; Figure 2$]$, reaching a maximum gain of $0.594 \mathrm{~kg} / \mathrm{d}$ (Figure 2), whereas Met + Cys values of 8.0 and $8.7 \mathrm{~g} / \mathrm{d}$ promoted gains of 0.500 and $0.542 \mathrm{~kg} / \mathrm{d}$, respectively.

\section{Gain Composition}

Figure 3 shows the EB gain values for the different age groups. For the younger group, 8 to $30 \mathrm{~d}$, no effect of Met + Cys increase on the deposition of CP $(P=0.803)$, EE $(P=0.338)$, or MM $(P=0.129)$ was observed, with average weight gain values of $0.053 \pm$ 


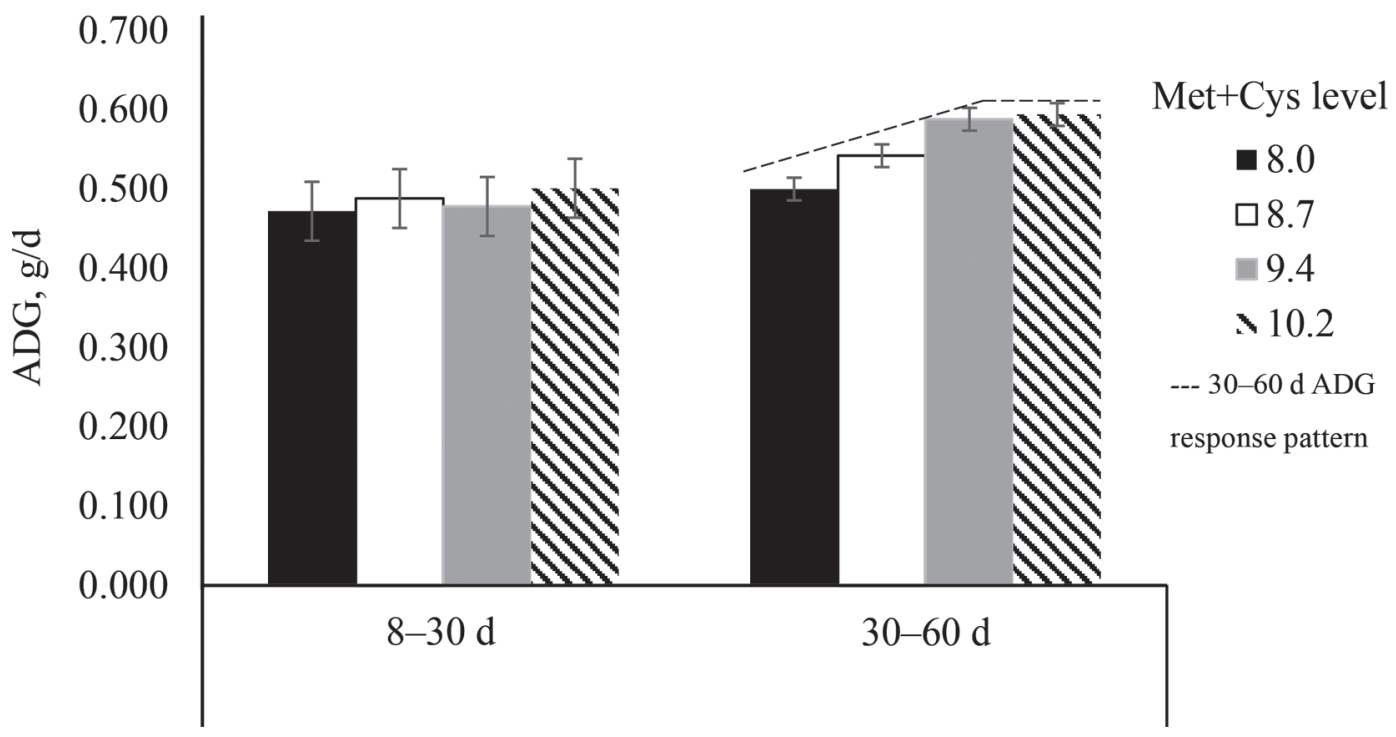

Figure 2. Average daily gain of liquid-fed crossbreed calves fed increasing Met + Cys levels (g/d). Newborn calves 8 to $30 \mathrm{~d}$, and pre-weaned calves 30 to $60 \mathrm{~d}(P=0.001)$. Error bars represent square mean error of LSM.

$0.003,0.054 \pm 0.002$, and $0.009 \pm 0.001 \mathrm{~kg} / \mathrm{kg}$ of EB per d, respectively. However, it was observed a Met + Cys breakpoint at $8.41 \mathrm{~g} / \mathrm{d}$ for 30 to $60 \mathrm{~d}$ EB protein gain, with a maximum daily gain of $0.083 \mathrm{~kg} / \mathrm{d}(\mathrm{Y}=$ $-0.438+0.062 \times$ Met + Cys $P=0.087 ; \mathrm{R}^{2}=0.17 ;$ $\mathrm{MSE}=0.018$; Figure 3$)$. Gains in $\mathrm{EE}(P=0.163)$ and MM $(P=0.168)$ did not vary with the increase in Met + Cys (Figure 3), with averages of $0.046 \pm 0.004$ and $0.018 \pm 0.002 \mathrm{~kg} / \mathrm{kg}$ of $\mathrm{EB} / \mathrm{d}$ for the respective components.
The gain of $\mathrm{CP}, \mathrm{EE}$, and MM in carcasses for different age groups is shown in Figure 4 . For the 8 to $30 \mathrm{~d}$ group, gains of $\mathrm{CP}(P=0.168), \mathrm{EE}(P=0.830)$, and MM $(P=0.618)$ did not vary according to the Met + Cys increment, with averages of $0.052 \pm 0.002,0.031$ \pm 0.002 , and $0.013 \pm 0.002 \mathrm{~kg} / \mathrm{kg}$ of carcass $/ \mathrm{d}$ for the respective components. A quadratic pattern response was observed for protein gain in 30 to $60 \mathrm{~d}$ carcasses $\left(\mathrm{Y}=-0.0188 \times\right.$ Met $+\mathrm{Cys}^{2}+0.353 \times$ Met + Cys $-1.589 ; P=0.053 ; \mathrm{R}^{2}=0.845 ; \mathrm{MSE}=0.014$; Figure

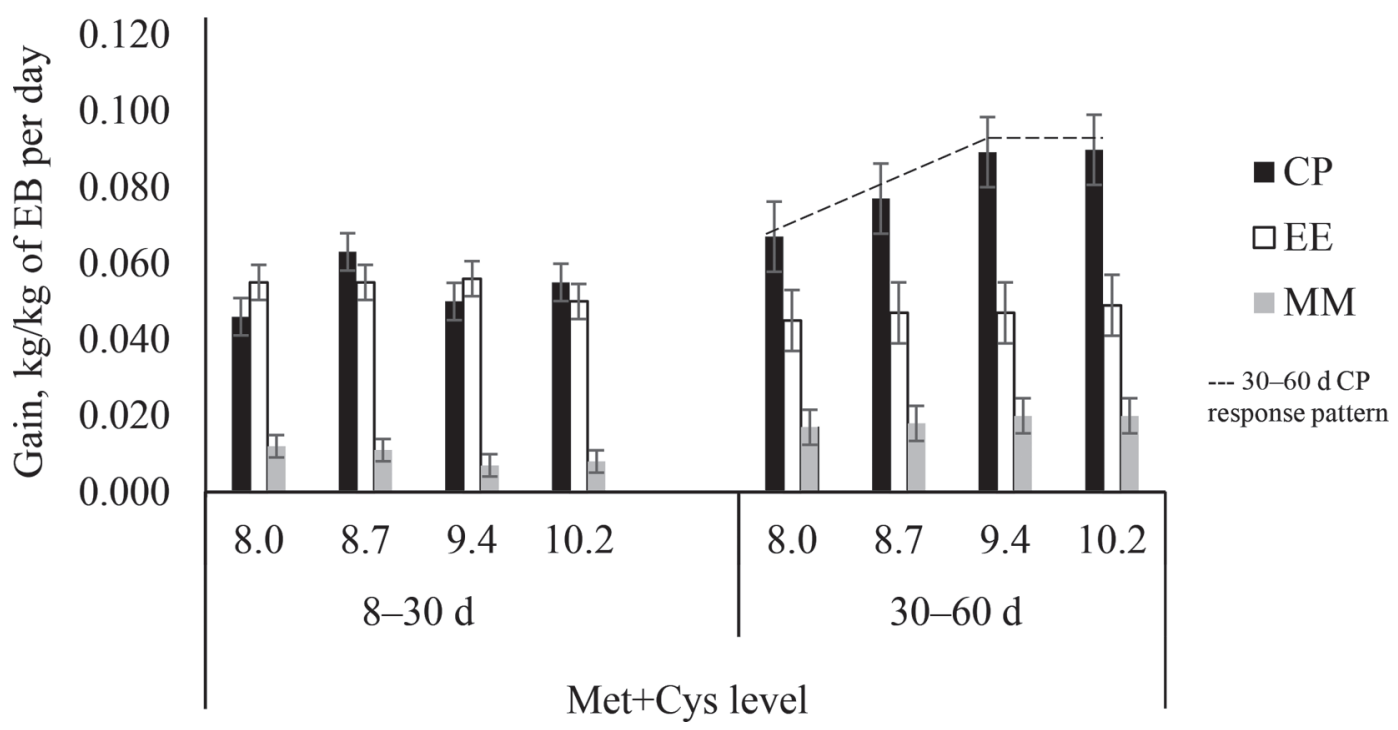

Figure 3. Empty body (EB) gain composition of CP, ether extract (EE), and mineral matter (MM) of liquid-fed crossbreed calves fed increasing Met + Cys levels $(\mathrm{g} / \mathrm{d})$. Newborn calves 8 to $30 \mathrm{~d}$, and pre-weaned calves 30 to $60 \mathrm{~d}(P=0.087)$. Error bars represent square mean error of LSM. 


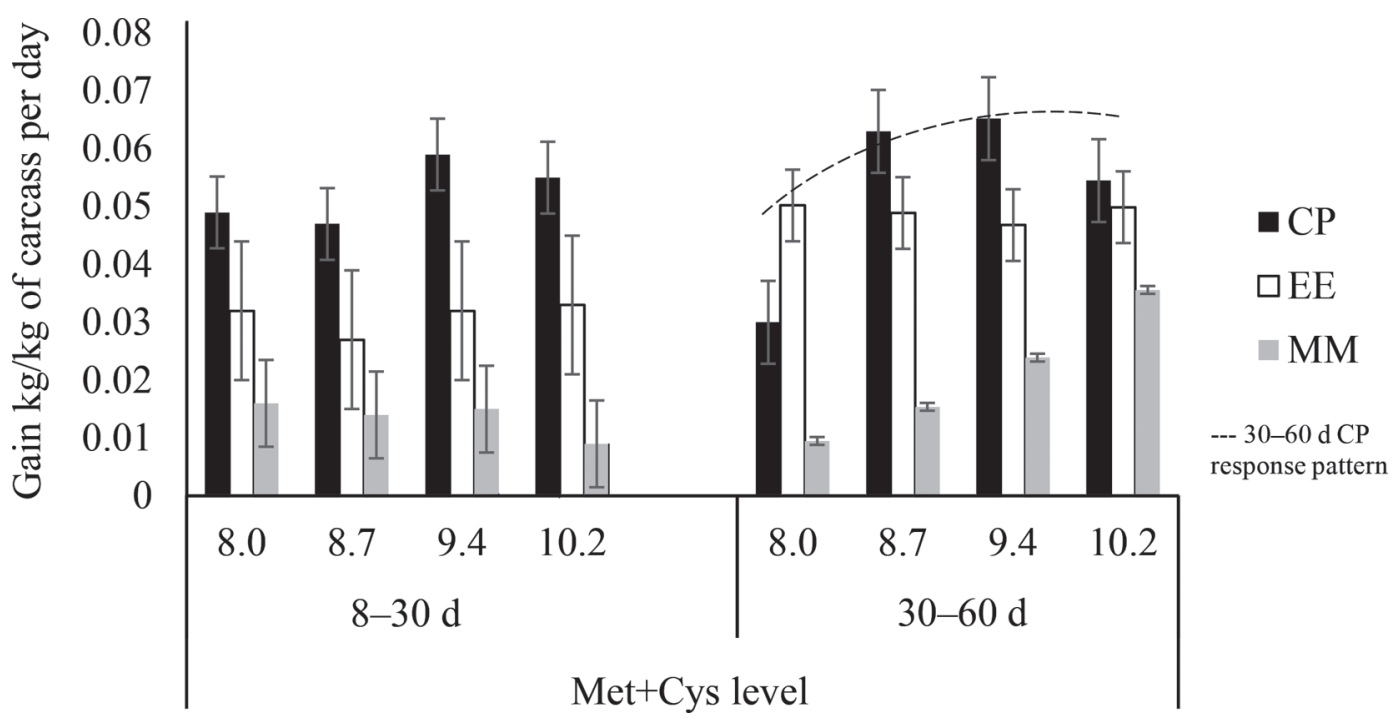

Figure 4. Carcass gain composition of CP, ether extract (EE), and mineral matter (MM) of liquid-fed crossbreed calves fed increasing Met + Cys levels $(\mathrm{g} / \mathrm{d})$. Newborn calves 8 to $30 \mathrm{~d}$, and pre-weaned calves 30 to $60 \mathrm{~d}(P=0.053)$. Error bars represent square mean error of LSM.

4), where the maximum estimated gain was $0.067 \mathrm{~g} / \mathrm{d}$, with a level of Met + Cys of $9.38 \mathrm{~g} / \mathrm{d}$. The Met + Cys level did not affect the EE gain $(P=0.970)$, with an average gain of $0.049 \pm 0.05 \mathrm{~kg} / \mathrm{kg}$ of carcass per $\mathrm{d}$. In contrast, MM gain had a linear growth behavior in relation to Met + Cys increase $(\mathrm{Y}=0.0015 \times$ Met + Cys $\left.-0.0745 ; P=0.004 ; \mathrm{R}^{2}=0.329 ; \mathrm{MSE}=0.004\right)$.

The gains of $\mathrm{CP}, \mathrm{EE}$, and $\mathrm{MM}$ in the organs and viscera of calves of the 2 different ages groups was also evaluated (Figure 5). For the 8 to $30 \mathrm{~d}$ group, the gains of $\mathrm{CP}(P=0.495), \mathrm{EE}(P=0.880)$, and $\mathrm{MM}(P=$ 0.420 ) did not vary according to the Met + Cys increment, with average values of $0.024 \pm 0.001,0.02 \pm$ 0.001 , and $0.003 \pm 0.001 \mathrm{~kg} / \mathrm{kg}$ of organs and viscera per day for the respective components. The maximum 30 to $60 \mathrm{~d}$ protein gain in organs and viscera was obtained at $9.55 \mathrm{~g} / \mathrm{d}$ according to the broken-line analysis $(\mathrm{Y}=-0.0268+0.0033 \times$ Met + Cys; $P=0.038 ;$ $\mathrm{R}^{2}=0.550 ; \mathrm{MSE}=0.0000043 ;$ Figure 5), reaching a maximum gain of $0.010 \mathrm{~kg} / \mathrm{d}$. No significant difference was observed in gains of $\mathrm{EE}(P=0.127)$ and $\mathrm{MM}(P=$ 0.783 ) when Met + Cys increased, with average gains of $0.014 \pm 0.001$ and $0.001 \pm 0.0002 \mathrm{~kg} / \mathrm{kg}$ of organs and viscera/d for the respective components.

The CP and EE in the EB composition of the 8 to 30 $\mathrm{d}$ group did not vary as a function of Met + Cys levels $(P=0.987 ; P=0.752)$, with average values of $8.81 \pm$ 0.106 and $4.09 \pm 0.129 \mathrm{~kg}$, respectively. For the 30 to $60 \mathrm{~d}$ group, body protein showed a quadratic pattern when Met + Cys increase, with the highest value of $11.94 \mathrm{~kg} / \mathrm{kg}$ of EB for Met + Cys of $9.81 \mathrm{~g} / \mathrm{d}$ (Y = $-0.644 \times$ Met $+\mathrm{Cys}^{2}+12.64 \times$ Met + Cys -50.083 ;
$P=0.088 ; \mathrm{R}^{2}=0.632 ; \mathrm{MSE}=0.289 ;$ Figure 6$)$. Body fat also showed a quadratic response to MC; however, it showed a converse response to protein, with the lowest estimated value of $5.35 \mathrm{~kg} / \mathrm{EB}$ for the Met + Cys of $8.97 \mathrm{~g} / \mathrm{d}\left(\mathrm{Y}=0.646 \times \mathrm{MC}^{2}-11.591 \times \mathrm{Met}+\mathrm{Cys}+\right.$ 57.357; $P=0.005 ; \mathrm{R}^{2}=0.478 ; \mathrm{MSE}=0.140$; Figure 6 ). Mineral matter composition in both age groups did not vary when Met + Cys increased, with averages of 1.83 and $2.35 \mathrm{~kg} / \mathrm{EB}$ for 8 to $30 \mathrm{~d}(P=0.129)$ and 30 to 60 $\mathrm{d}(P=0.163)$, respectively.

\section{DISCUSSION}

\section{$A D G$ and Digestibility}

Average calf weight did not vary when Met + Cys increased in the diet, possibly due to the relatively short period of the nurturing phase. This is a natural limitation intrinsic to this type of study, because the liquid-feeding phase of calves traditionally ends around $60 \mathrm{~d}$ of life; and from this point on, there is a greater ruminal development, which can lead to further problems such as alteration of AA profiles in the rumen after consumption. However, Met + Cys increases did alter other variables evaluated as discussed below.

The younger calves ( 8 to $30 \mathrm{~d}$ ) did not have an increment in the ADG as a function of different Met + Cys levels values with an average weight gain of $0.480 \mathrm{~kg} / \mathrm{d}$, which was considered below the expectations for crossbred calves, when compared with calves fed only with whole milk (WM), showing an ADG of $0.794 \mathrm{~kg} / \mathrm{d}$ in a study by Silva et al. (2015). This should be noted when 


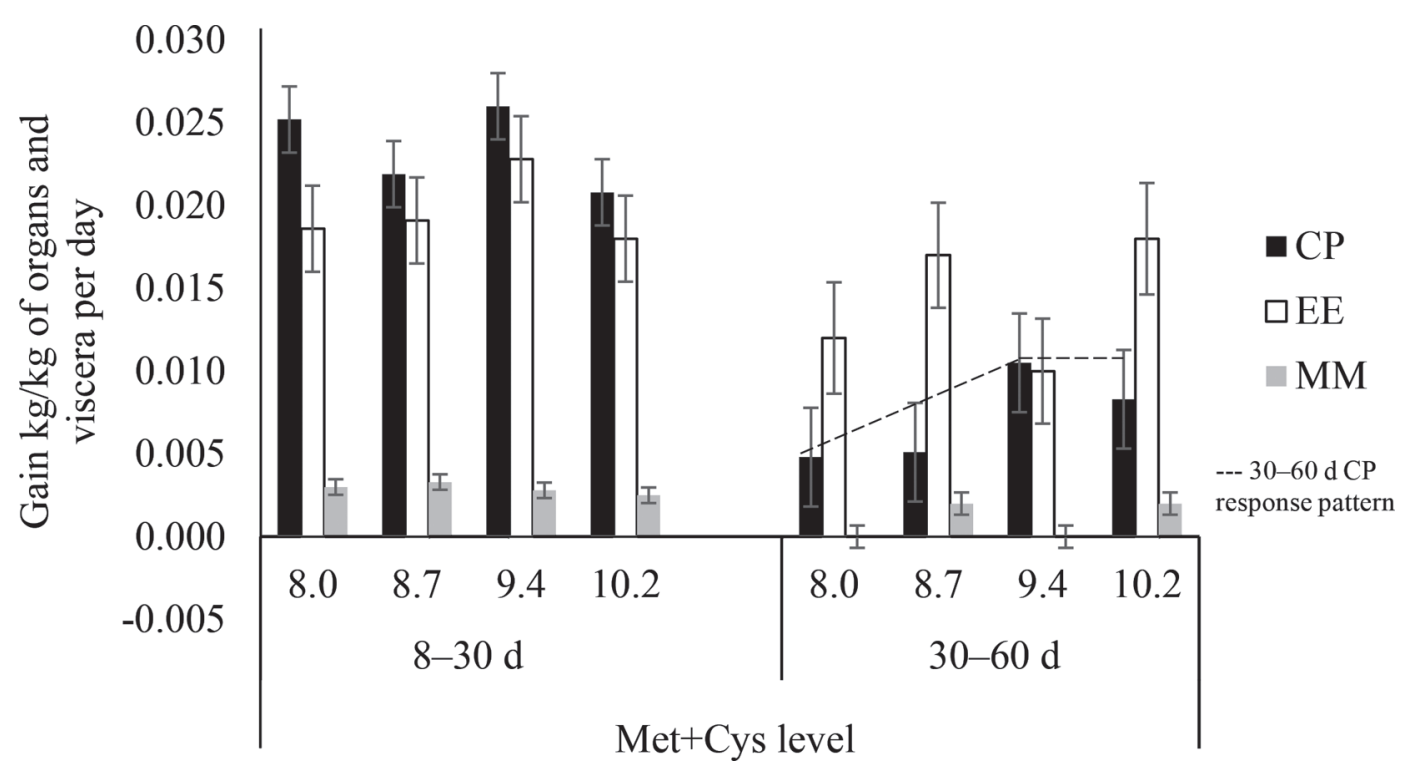

Figure 5. Organ and viscera gain composition of CP, ether extract (EE), and mineral matter (MM) of liquid-fed crossbreed calves fed increasing Met + Cys levels (g/d). Newborn calves 8 to $30 \mathrm{~d}$, and pre-weaned calves 30 to $60 \mathrm{~d}(P=0.038)$. Error bars represent square mean error of LSM.

taking into account the DMI per unit of BRW for 8 to $30 \mathrm{~d}$ (DMI of $20.1 \mathrm{~g} / \mathrm{kg}$ of BRW) compared with calves fed WM (for DMI of $14.4 \mathrm{~g} / \mathrm{kg}$ of BRW).

The low performance observed for 8 to $30 \mathrm{~d}$ calves could be associated with specific digestive patterns of MR, such as its relatively fast passage rate through the gastrointestinal tract and due to the low ability of the gut of young calves to digest non-milk components, considering the limited pancreatic enzyme production
(Tanan, 2005). The scenario could be confirmed by our diarrhea events for calves 8 to $15 \mathrm{~d}$ old, which is typical in that period (Marcondes et al., 2016). Also, comparing WM and MR responses in gastrointestinal tract, the milk, even as a liquid feed, is high in casein (low concentration component in MR protein), allowing milk coagulation in the abomasum by rennin, or chymosin and chloric acid, forming a fat and protein clot compound (Pond et al., 2005). Thus, the clot is slowly

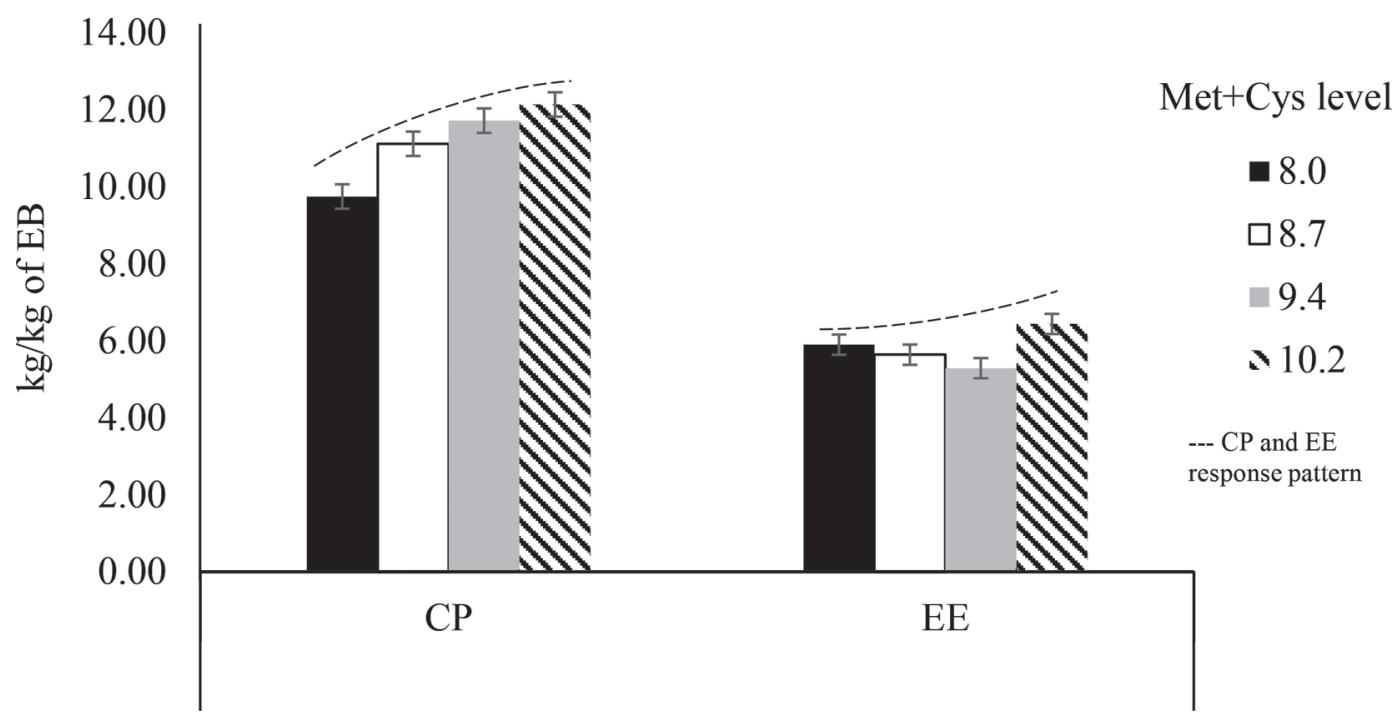

Figure 6. Empty body (EB) composition of liquid-fed crossbred calves fed increasing Met + Cys levels $(\mathrm{g} / \mathrm{d})$ slaughtered at $60 \mathrm{~d}(P<0.10)$. $\mathrm{EE}=$ ether extract. Error bars represent square mean error of LSM. 
digested between 12 and $18 \mathrm{~h}$ by abomasum enzymes, promoting high milk retention in the gastrointestinal tract and, consequently, high nutrient digestibility (Mylrea, 1966), which do not occur to the same extent for $\mathrm{MR}$ as cited above.

In addition, the MR had a relatively high $\mathrm{CF}$ content $(0.74 \mathrm{~g} / \mathrm{kg}$ of DM; Table 1$)$, which is considered above the acceptable inclusion level in MR for young calves $(0.15 \%$, BAMN, 2014; 0.5\%, Davis and Drackley, 1998). The high inclusion observed is a consequence of the non-milk protein source included in MR. Soybean and wheat are the most used ingredients as non-milk protein source in MR, and besides the premise that soy proteins are less digestible than milk proteins, because of the immature digestive tract of young calves (Tanan, 2005), soy proteins may contain anti-nutritional factors, such as trypsin inhibitor, antigenic proteins (glycinin and $\beta$-conglycinin), and indigestible sugar (verbascose and oligosaccharides; Huisman and Jansman, 1989), and those issues may be associated with digestive disruptions (França et al., 2011; Morrison, 2015) and the lower small intestine development in calves (Drackley et al., 2006). Even with industrial treatments of vegetable protein sources, soy and wheat protein inclusion in MR may be linked to calves' low performance. Huang et al. (2015) reported an ADG of 0.698 and $0.627 \mathrm{~kg} / \mathrm{d}$ in 8-wk-old calves fed MR based on soybean protein concentrate and hydrolyzed wheat protein, respectively, which were inferior to ADG when MR based on milk protein was fed to the calves $(0.775 \mathrm{~kg} / \mathrm{d})$.

Later in life, with a more advanced gastrointestinal tract development, the capacity to digest more complex non-milk proteins and carbohydrates increases (Lee et al., 2012; Davis and Drackley, 1998), which is confirmed by this study (Figure 1), when a greater digestibility was observed in 30 to $60 \mathrm{~d}$ calves $(96.5 \% \mathrm{OM}, 92.3 \%$ $\mathrm{CP})$ when compared with 8 to $30 \mathrm{~d}$ calves $(94.6 \% \mathrm{OM}$ and $86.8 \% \mathrm{CP}$ ).

The ADG for 30 to $60 \mathrm{~d}(0.556 \mathrm{~kg} / \mathrm{d})$ was also below the values observed by Silva et al. (2015; 0.794 $\mathrm{kg} / \mathrm{d}$ ), relating nutrient intake per unit of BRW, DMI of $17.7 \mathrm{~g} / \mathrm{kg}$ of BRW, and a DMI of $14.4 \mathrm{~g} / \mathrm{kg}$ of BRW, respectively. The OM digestibility observed for 30 to $60 \mathrm{~d}$ calves versus calves up to $64 \mathrm{~d}$ fed WM (Silva et al., 2015) was similar, 96.5 versus $96.9 \%$, respectively. Even in the MR having considerable levels of $\mathrm{CF}$, other dietary ingredients could have contributed to improvement of OM digestibility, such as greater lactose inclusion (44\% as fed, guaranteed level of inclusion according to MR packaging), greater EE digestibility, and use of crystallized AA, which represented $26 \%$ of CP in the diet. Crystallized AA have high biological value and digestibility and were tested in nonruminant diets (Krehbiel and Matthews, 2003). Despite this similarity in $\mathrm{OM}$ digestibility, the performance of calves fed MR was lower than those fed WM (Silva et al., 2015), and this difference may be associated with EE concentration in MR $(15.1 \mathrm{~g} / \mathrm{kg}$ of DM) versus WM $(28.5 \mathrm{~g} / \mathrm{kg}$ of DM; Silva et al., 2015). Thus, the experimental diets allowed less ME (4.1 Mcal $/ \mathrm{kg}$ of DM) than diets based on WM (4.8 Mcal $/ \mathrm{kg}$ of DM; Silva et al., 2015), as also reported by Khan et al. (2007). Finally, it should be noted that treatments with 8.0 and $8.7 \mathrm{~g} / \mathrm{d}$ of Met + Cys did have their performance impaired by the suboptimum Lys level, which affected all comparisons with literature findings for whole milk (Silva et al., 2015).

The inclusion of 9.4 and $10.2 \mathrm{~g} / \mathrm{d}$ of Met + Cys had a Met intake greater than other experimental diets; thus, better performance was expected from animals fed these diets, irrespective of the physiological phase. The absence of responses for 8 to $30 \mathrm{~d}$ calves for AA increment suggests that $8.0 \mathrm{~g} / \mathrm{d}$ of Met + Cys or $5.0 \mathrm{~g} / \mathrm{d}$ of Met met the requirements for that physiological phase. Wang et al. (2012) proposed that for calves up to 8 wk of age fed MR (soy protein inclusion) + starter + hay, an ideal Met inclusion in the diet of $5.7 \mathrm{~g} / \mathrm{d}$ would guarantee ADG between 0.48 and $0.50 \mathrm{~kg} / \mathrm{d}$, which is close to what we have observed in the present study.

On the other hand, the responses in performance observed for 30 to $60 \mathrm{~d}$ calves suggest that the greater ADG might have been linked to a specific and unique role that Met plays as a donor of the methyl radical for reactions of methylation in mammals (Waterland, 2006). Beyond that, Met is important for the regulation of gene expressions and of protein functions and metabolism of ARN, thus increasing body growth (Wu, 2009). Even considering that the 8 to $30 \mathrm{~d}$ calves were more dependent on the liquid diet, and the ME offered per BRW was higher when compared with 30 to $60 \mathrm{~d}$, neonates were not effective in converting MR into BW. However, our data corroborate with the findings of Hill et al. (2009), who observed ADG of $0.47 \mathrm{~kg} / \mathrm{d}$ for calves up to $28 \mathrm{~d}$ fed milk replacer ( $25 \%$ of $\mathrm{CP}$ ) and starter.

The inference above can be reaffirmed using the data observed for 30 to $60 \mathrm{~d}$. The Met + Cys inclusion breakpoint estimated at $9.45 \mathrm{~g} / \mathrm{d}$ promoted the greatest gain of $0.594 \mathrm{~kg} / \mathrm{d}$ (Figure 2). The breakpoint indicates that with a Met + Cys inclusion of $9.45 \mathrm{~g} / \mathrm{d}$, sulfur AA concentration met Met + Cys requirements for crossbred calves' performance aged up to $60 \mathrm{~d}$. Even at $9.45 \mathrm{~g} / \mathrm{d}$ of Met + Cys, for each gram of Met added to the diet, there was an increment of $10.9 \mathrm{~g} / \mathrm{d}$ in animal BW (Figure 2). The lowest intake of Met supplied to animals in the 8.0 and $8.7 \mathrm{~g} / \mathrm{d}$ fostered ADG values of 
0.500 and $0.542 \mathrm{~g} / \mathrm{d}$, which are 15.8 and $8.75 \%$ smaller, respectively, than the gain resulting from an optimal Met inclusion.

\section{Gain Composition}

For the group 30 to $60 \mathrm{~d}$, we observed a Met + Cys inclusion breakpoint estimated at $8.41 \mathrm{~g} / \mathrm{d}$ for protein deposition of $0.083 \mathrm{~kg} / \mathrm{d}$ (Figure 3); for each gram of Met added to the diet, the calves deposited $2.7 \mathrm{~g} / \mathrm{d}$ of protein in EB. In terms of protein gain in the 30 to 60 $\mathrm{d}$ carcass, a Met + Cys inclusion of $9.38 \mathrm{~g} / \mathrm{d}$ allowed the highest gain, estimated at $0.067 \mathrm{~kg} / \mathrm{d}$ (Figure 4).

In terms of organs and viscera, the maximum deposition was $0.010 \mathrm{~kg} / \mathrm{d}$ of protein with a Met + Cys inclusion of $9.55 \mathrm{~g} / \mathrm{d}$, and for each gram of Met added to the diet, the calves deposited $0.8 \mathrm{~g}$ of protein (Figure 5).

The addition of crystalline Met in diets of calves older than $30 \mathrm{~d}$ allowed a higher deposition of protein in EB $(\mathrm{kg} / \mathrm{d})$; this behavior was observed when the body components of the carcass and organs and viscera were evaluated separately. After the first analysis, we believed that this protein gain in $\mathrm{EB}$ was concentrated in the animals' organs and viscera due to the high demand of sulfur AA of these organs, particularly Cys (Fang et al., 2010; Jankowski et al., 2014); this is particularly the case during the first months of life, when the organs and the gastrointestinal tract grow at high rates (Bauchart-Thevret et al., 2009). However, it is possible to draw the conclusion that a Met + Cys inclusion between 8.41 to $9.81 \mathrm{~g} / \mathrm{d}$ not only maximized organ and viscera gain, but also increased the muscular deposition in the carcasses of these animals. Because the supply of EE and MM was similar across Met + Cys levels, it was expected that the gain of both components in carcass, organs, and viscera did not vary.

\section{Body Composition}

The body composition of calves at $60 \mathrm{~d}$ (Figure 6) reflected the greater protein gain in $\mathrm{EB}$, carcass, and organs and viscera due to the Met + Cys increase in the diet (Figure 3, 4, and 5; respectively), reaffirming the essential role of Met for protein synthesis, genic expression, and energetic metabolism of the muscle (Tesseraud et al., 2009; Wu et al., 2014). Consistently, when protein was deposited, a lower amount of energy was available for fat deposition (Figure 6).

According to data observed in the present study, the Met + Cys concentration in WM (4.04 g/100 g of $\mathrm{CP}$ ) is below the optimal level observed for best calf performance $(4.4 \mathrm{~g} / 100 \mathrm{~g}$ of $\mathrm{CP})$. Consequently, Met + Cys are actually low in milk proteins, as proposed by Hill et al. (2008) and Castro et al. (2016), even WM being considered the best protein and energy source for calves. In addition, it is worth noting that the MR used in this study is even poorer in Met + Cys (2.8 $\mathrm{g} / 100 \mathrm{~g}$ of $\mathrm{CP}$ ); therefore, we suggest that companies that produce MR should add crystalline Met to their products, thereby ensuring a qualitatively higher Met + Cys product for calves' best performance.

In conclusion, our data indicate that increasing Met + Cys in the diets positively influences the performance of liquid-fed calves fed only milk replacer containing soy protein concentrate and wheat protein isolate. Calves at 8 to $30 \mathrm{~d}$ had the $\mathrm{AA}$ requirements met with Met + Cys inclusion of $8.0 \mathrm{~g} / \mathrm{d}$ in the diet. In addition, the Met + Cys proportion, which allowed the best performance for pre-weaned calves, aged between 30 and 60 $\mathrm{d}$, ranged between 8.41 to $9.81 \mathrm{~g} / \mathrm{d}$. Despite the great advances of this study for young ruminants, more data are needed to validate the results observed here.

\section{ACKNOWLEDGMENTS}

The authors are grateful to DSM Company (Heerlen, the Netherlands) and Ajinomoto Co. Inc. (Tokyo, Japan) for milk replacer and amino acid supply. Also, we are grateful to the Brazilian foundations, Coordenação de Aperfeiçoamento de Pessoal de Nível Superior (CAPES), Conselho Nacional de Desenvolvimento Científico e Tecnológico (CNPq), Fundação de Amparo à Pesquisa do estado de Minas Gerais (FAPEMIG), Instituto Nacional de Ciência e Tecnologia de Ciência Animal (INCT-CA), and Brazilian Agricultural Research Corporation, Embrapa Dairy Cattle (Juiz de Fora, MG, Brazil), for their help in this study.

\section{REFERENCES}

Abe, M., T. Iriki, and M. Funaba. 1997. Lysine deficiency in postweaned calves fed corn and corn gluten meal diets. J. Anim. Sci. 75:1974-1982.

Agricultural and Food Research Council. 1993. Energy and Protein Requirements of Ruminants. An advisory manual prepared by the AFRC Technical Committee on Response to Nutrients. CAB International, Wallingford, Oxon, UK.

American Oil Chemists' Society (AOCS). 2004. Official Methods and Recommended Practices. 5th ed. AOCS, Urbana, IL.

AOAC International. 2000. Official Methods of Analysis. 17th ed. AOAC International, Gaithersburg, MD.

AOAC International. 2005. Official Methods of Analysis. 18th ed. AOAC International, Gaithersburg, MD.

Bauchart-Thevret, C., B. Stoll, and D. G. Burrin. 2009. Sulfur amino acid deficiency upregulates intestinal methionine cycle activity and suppresses epithelial growth in neonatal pigs. Nutr. Res. Rev. Journal. 22:175-187.

Bovine Alliance on Management and Nutrition (BAMN). 2014. A guide to calf milk replacers: Types, use, and quality. Accessed Sep. 28, 2017. https://www.aphis.usda.gov/animal_health/nahms/ dairy/downloads/bamn/BAMN08_GuideMilkRepl.pdf.

Castro, J. J., G. H. Hwang, A. Saito, D. A. Vermeire, and J. K. Drackley. 2016. Assessment of the effect of methionine supplementation and inclusion of hydrolyzed wheat protein in milk protein- 
based milk replacers on the performance of intensively fed Holstein calves. J. Dairy Sci. 99:6324-6333.

Commonwealth Scientific and Industrial Research Organization. 2007. Nutrient Requirements of Domesticated Ruminants. Australia Agricultural Council, CSIRO Publishing, Victoria, Australia.

Conde-Aguilera, J. A., R. Barea, N. Le Floc'h, L. Lefaucheur, and J. van Milgen. 2010. A sulfur amino acid deficiency changes the amino acid composition of body protein in piglets. Animal 4:13491358.

Davis, C. L., and J. K. Drackley. 1998. The Development, Nutrition, and Management of the Young Calf. Iowa State University Press, Ames.

Deelen, S. M., T. L. Ollivett, D. M. Haines, and K. E. Leslie. 2014. Evaluation of a Brix refractometer to estimate serum immunoglobulin G concentration in neonatal dairy calves. J. Dairy Sci. 97:3838-3844.

Detmann, E., M. A. Souza, S. C. Valadares Filho, A. C. Queiróz, T. T. Berchielli, E. O. S. Saliba, L. S. Cabral, D. S. Pina, M. M. Ladeira, and J. A. G. Azevedo. 2012. Methods for Feed Analysis, INCT, Animal Science. Suprema Gráfica, Visconde do Rio Branco, Brazil.

D'Mello, J. P. F. 2003. Amino Acids in Animal Nutrition. 2nd ed. CABI Publishing, Edinburgh, UK.

Drackley, J. K., R. M. Blome, K. S. Bartlett, and K. L. Bailey. 2006. Supplementation of $1 \%$ L-glutamine to milk replacer does not overcome the growth depression in calves caused by soy protein concentrate. J. Dairy Sci. 89:1688-1693.

Erickson, P. S., D. J. Schauff, and M. R. Murphy. 1989. Diet digestibility and growth of Holstein calves fed acidified milk replacers containing soy protein concentrate. J. Dairy Sci. 72:1528-1533.

Fang, Z., K. Yao, X. Zhang, S. Zhao, Z. Sun, G. Tian, B. Yu, Y. Lin, B. Zhu, G. Jia, K. Zhang, D. Chen, and D. Wu. 2010. Nutrition and health relevant regulation of intestinal sulfur amino acid metabolism. Amino Acids 39:633-640.

França, S. R. A., S. G. Coelho, A. U. Carvalho, R. G. R. Martins, and S. L. M. Ribeiro. 2011. Desempenho de bezerros alimentados usando de sucedâneo até 56 dias de idade. Rev. Ceres 58:790-793.

Hill, S. R., B. A. Hopkins, S. Davidson, S. M. Bolt, D. E. Diaz, C. Brownie, T. Brown, G. B. Huntington, and L. W. Whitlow. 2009. The addition of cottonseed hulls to the starter and supplementation of live yeast or mannanoligosaccharide in the milk for young calves. J. Dairy Sci. 92:790-798.

Hill, T. M., H. G. Bateman, J. M. Aldrich, R. L. Schlotterbeck, and K. G. Tanan. 2008. Optimal concentration of lysine, methionine, and threonine in milk replacers for calves less than five weeks of age. J. Dairy Sci. 91:2433-2442.

Hill, T. M., J. D. Quigley, H. G. Bateman II, J. M. Aldrich, and R. L. Schlotterbeck. 2016. Source of carbohydrate and metabolizable lysine and methionine in the diet of recently weaned dairy calves on digestion and growth. J. Dairy Sci. 99:2788-2796.

Huang, K., Y. Tu, B. Si, G. Xu, J. Guo, F. Guo, C. Yang, and Q. Diao. 2015. Effects of protein sources for milk replacers on growth performance and serum biochemical indexes of suckling calves. Anim. Nutr. 1:349-355.

Huisman, J., and A. J. M. Jansman. 1989. Antinutritional factors (ANFs) in the nutrition of monogastric farm animals. Pages 17-35 in Nutrition and Digestive Physiology in Monogastric Farm Animals. E. J. van Weerden, and J. Huisman, ed. Pudoc, Wageningen, the Netherlands.
Jankowski, J., M. Kubińska, and Z. Zduńczyk. 2014. Nutritional and immunomodulatory function of methionine in poultry diets-A review. Ann. Anim. Sci. 14:17-31.

Khan, M. A., H. J. Lee, W. S. Lee, H. S. Kim, S. B. Kim, K. S. Ki, J. K. Ha, H. G. Lee, and Y. J. Choi. 2007. Pre- and postweaning performance of Holstein female calves fed milk through step-down and conventional methods. J. Dairy Sci. 90:876-885.

Krehbiel, C. R., and J. C. Matthews. 2003. Absorption of amino acids and peptides. Pages 41-70 in Amino Acids in Animal Nutrition. J. P. F. D'Mello, ed. CABI Publishing, London, UK.

Lee, C., A. N. Hristov, T. W. Cassidy, K. S. Heyler, H. Lapierre, G. A. Varga, M. J. de Veth, R. A. Patton, and C. Parys. 2012. Rumenprotected lysine, methionine, and histidine increase milk protein yield in dairy cows fed a metabolizable protein-deficient diet. J. Dairy Sci. 95:6042-6056.

Marcondes, M. I., T. R. Pereira, J. C. C. Chagas, E. A. Filgueiras, M. M. D. Castro, G. P. Costa, A. L. L. Sguizzato, and R. D. Sainz. 2016. Performance and health of Holstein calves fed different levels of milk fortified with symbiotic complex containing pre- and probiotics. Trop. Anim. Health Prod. 48:1555-1560.

Morrison, S. Y. 2015. Amino acid supplementation of calf milk replacers containing bovine plasma protein. MS Thesis. Department of Animal Sciences, University of Illinois, Urbana-Champaign.

Mylrea, P. J. 1966. Digestion of milk in young calves. I. Flow and acidity of the contents of the small intestine. Res. Vet. Sci. 7:333-341.

NRC. 2001. Nutrient Requirements of Dairy Cattle, 7th ed. National Academies Press, Washington, DC.

Pond, W. G., D. C. Church, K. R. Pond, and P. A. Schoknecht. 2005. Basic Animal Nutrition and Feeding. Fifth Edition. Wiley, Hoboken, NJ.

Rutherfurd, S. M., and P. J. Moughan. 1998. The digestible amino acid composition of several milk proteins: Application of a new bioassay. J. Dairy Sci. 81:909-917.

Silva, A. L., M. I. Marcondes, E. Detmann, F. S. Machado, S. C. Valadares Filho, A. S. Trece, and J. Dijkstra. 2015. Effects of raw milk and starter feed on intake and body composition of Holstein $\times$ Gyr male calves up to 64 days of age. J. Dairy Sci. 98:2641-2649.

Tanan, K. G. 2005. Nutrient sources for liquid feeding of calves. Pages 83-112 in Calf and Heifer Rearing. P. C. Garnsworthy, ed. Nottingham University Press., Nottingham, UK.

Tesseraud, S., I. Bouvarel, A. Collin, E. Audouin, S. Crochet, I. Seilez, and C. Leterrier. 2009. Daily variations in dietary lysine content alter the expression of genes related to proteolysis in chicken pectoralis major muscle. J. Nutr. 139:38-43.

Wang, J., Q. Diao, Y. Tu, N. Zhang, and X. Xu. 2012. The limiting sequence and proper ratio of lysine, methionine and threonine for calves fed milk replacers containing soy protein. Asian-Australas. J. Anim. Sci. 25:224-233.

Waterland, R. A. 2006. Assessing the effects of high methionine intake on DNA methylation. J. Nutr. 136:1706S-1710S.

Wu, G. 2009. Amino acids: Metabolism, functions, and nutrition. Amino Acids 37:1-17.

Wu, G., F. W. Bazer, Z. Dai, D. Li, J. Wang, and Z. Wu. 2014. Amino acid nutrition in animals: Protein synthesis and beyond. Annu. Rev. Anim. Biosci. 2:387-417.

Wu, G., W. G. Pond, and T. L. Ott. 1998. Maternal dietary protein deficiency decreases amino acid concentrations in fetal plasma and allantoic fluid of pigs. J. Nutr. 128:894-902. 